\title{
Preconditioning as a Possible Protective Mechanism in the Spinal Cord Ischemia
}

\author{
Jozef Radoňak ${ }^{1}$, Dáša Č́žková 2 , Naděžda Lukáčová ${ }^{2}$, Darina Kluchová3, \\ Alexander Ostró ${ }^{4}$, Ján Gálik ${ }^{2}$ \\ ${ }^{1}$ Ist $^{\text {st }}$ Surgical Clinic, P.J. Šafárik University and University Hospital, Košice \\ ${ }^{2}$ Institute of Neurobiology, Centre of Excellence, SAS, Košice, \\ ${ }^{3}$ Department of Anatomy, University of P. J. Šafárik, Košice \\ ${ }^{4} I^{\text {nd }}$ Gynaecological Clinic P.J. Šafárik University and University Hospital, Košice, Slovakia \\ Received November 14, 2006 \\ Accepted February 9, 2009
}

\begin{abstract}
The present study deals with the problem of spinal cord protection. The aim of this study was to simulate conditions during surgery on aortic aneurysm and to consider their possible utilisation in clinical practice. Wistar albino rats of both sexes were used in the experiment. Surgery was performed on the thoracic part of aorta.

The closure of aorta in duration of 12 min caused a neurological deficit in $81 \%$ of rats, 14 min of ischemia paralysed $90 \%$ of animals. Preconditioning with 3-min ischemia following $30 \mathrm{~min}$ recirculation improved the neurological score in the group with $12 \mathrm{~min}$ of ischemia after $48 \mathrm{~h}$, in which only $27 \%$ of rats were paralysed. The same preconditioning was performed in the group of animals with 14 min of ischemia, and as a consequence, $33 \%$ of rats were paralysed in that group.

Protection of the spinal cord during ischemia can be achieved by preconditioning. Thus the method of preconditioning appears to be a prospective technique for the improvement of the devastating neurological deficit after surgery on the aorta and has provided optimism that additional therapies will be possible in the future.
\end{abstract}

Paraplegia, ischemic preconditioning, thoracoabdominal aneurysm

Aneurysm of the thoracoabdominal part of the aorta represents $2-5 \%$ of overall aortic aneurysms. One of the most serious complications after surgery on the aorta is paralysis, developed as a result of a neurological deficit. Spinal cord as part of the central nervous system is extremely sensitive to ischemia. In spite of the well-known time for the safe return of blood supply, which is about $10 \mathrm{~min}$, the duration of surgery usually substantially exceeds this period (2 - 4 times). As a consequence, serious neurological devastations occur.

In the last decades a number of researchers and clinicians have been searching for an effective way of spinal cord protection during surgery on the aortic aneurysm. This study is focused on the experimental use of a short ischemic period as a method of preconditioning to a longer time of ischemia. The present experiment was carried out on experimental animals in order to contribute to present knowledge on spinal cord recovery from ischemic reperfusion injury.

\section{Materials and Methods}

Experiments were carried out in cooperation with the $\mathrm{I}^{\mathrm{st}}$ Surgical Clinic of the Medical Faculty of P. J. Šafárik University in Košice and with the Institute of Neurobiology of Slovak Academy of Sciences in Košice, Slovak Republic. The experiments were approved by the Ethics Committee of the Faculty of Medicine of P. J. Šafárik University in Košice and by the State Veterinary Administration of the Slovak Republic. Both sexes of Wistar albino rats were used in the experiment. The animals were anaesthetized with $4 \%$ halothane. The anaesthetized animals underwent thoracotomy and ischemia of the spinal cord was introduced according to model of Taira and Marsala (1996). The principle of this model is obturation of the aorta distal to the left subclavian artery and proximal to the diaphragm. For obturation a Fogarthy catheter inserted through the femoral artery was used. Proximal high blood pressure caused by clamping was decreased by partial exsanguination of rats through the cannulated common carotid artery to the heparinized reservoir. Carotid and caudal arteries were cannulated with

Address for correspondence:

Prof. MUDr. J. Radoňak, CSc.

I.chirurgická klinika LF UPJS

FN- L. Pasteura, Tr. SNP 1

04001 Košice, Slovak Republic 
radiopaque catheter G18 for continuous monitoring of blood pressure: proximal to clamped place of aorta distal to cross-clamped place of aorta.

The animals were divided into four experimental groups (each consisted of 12 animals) according to the duration of aortic cross-clamping and preconditioning time:

Group I - aortic occlusion for $12 \mathrm{~min}$

Group II - aortic occlusion for $14 \mathrm{~min}$

Group III - 3 min preconditioning +30 min recirculation +12 min aortic occlusion

Group IV - 3 min preconditioning +30 min recirculation +14 min aortic occlusion

Ischemic preconditioning was introduced by obturation of the aorta. The obturation was made by using an inflated balloon located immediately bellow the left subclavian artery in the duration of 3 min. After this time the aortic blood was released for $30 \mathrm{~min}$ for recirculation. Subsequently, another aortic obturation was made in the duration of 12 or 14 min (Plate XVIII, Fig. 1).

Results obtained from each of the experimental group were compared to sham operated animals. The neurological function of experimental animals was monitored twice: 12 and $48 \mathrm{~h}$ after surgery. The following indicators were monitored during the experiment:

- body temperature of the rat

- proximal and distal blood pressure

- the amount of exsanguinated blood released during partial exsanguination

- the level of glycaemia.

Rectal temperature was maintained at $37^{\circ} \mathrm{C}$ throughout the surgical procedure using a feedback regulated waterheating system. Common carotid and tail artery were cannulated for continuous monitoring of blood pressure by using the device LKM 220 Tesla. The measuring of blood pressure proximal and distal to the obturated part of the aorta is one of the most important indicators. Low values of blood pressure distal from the clamping confirm the completeness of aortic closure. Sufficient perfusion proximal to the aortic clamping is considered to be an important condition of animal survival in the experimental model of ischemia during partial exsanguination or reperfusion. In Table 1 values of blood pressure measured in the distal part of the body are presented.

The animals were partially exsanguinated to avoid fatal increase of blood pressure in the proximal part of the body following the inflating of the balloon. The arrangement of instruments for partial exsanguination is seen in Fig. 1.

A certain amount of blood was released to the reservoir by opening the valve in the cannula inserted into the common carotid artery. The amount of blood was regulated by the elevation of reservoir to the level above the experimental animal. The height of $54 \mathrm{~cm}$ represented a decrease of blood pressure to the required $5.3 \mathrm{kPa}$.

The volume of blood released to the reservoir in each experimental group of animals during ischemia is shown in Table 2. There were no significant differences between groups of animals ( $t$-test, $p>0.2)$.

Light microscopy

Forty-eight hours after surgery, the experimental animals were sacrificed with an intravenous injection of Thiopental and transcardially perfused with 4\% paraformaldehyde. Spinal cords were removed from vertebral canal, fixed in a solution of $4 \%$ paraformaldehyde, followed by fixation in $20 \%$ sucrose solution for $12 \mathrm{~h}$. For histochemical analysis horizontal sections of $42 \mu \mathrm{m}$ thickness were used. Finally, sections were processed for the examination by using:

1. Haematoxylin and eosin;

2. impregnated method according to Gallyas.

\section{Results}

Results of this study were based on the evaluation of:

- neurological status of animals - by using index of motor deficit

- histopathological examination of spinal cords from sections impregnated by Gallyas and stained with H\&E.

Index of motor deficit $=$ summation of mobility and stepping, i.e. the ability of the rat to extend lower extremities over the table edge.

Mobility

0 - normal walking

1- walking with slight difficulties

2- extremities slightly twisted off the body

3 - inability to lay extremities down the body

4- complete neurological deficit in using lower extremities

Stepping

0 - stretching extremities over the table edge without any problems

1 - failure to stretch extremities fully

2- inability to stretch lower extremities at all 
Neurological findings were scored on a six-point scale: $0=$ no neurological deficit, $6=$ complete paralysis. Each of the experimental groups of animals displayed different results according to index of motor deficit:

Group I. (12') - 5.65

Group II. (14') - 5.92

Group III. (3'prec $\left.+12^{\prime}\right)-3.07$

Group IV. (3'prec $\left.+14^{\prime}\right)-4.0$

Results of the index of motor deficit are shown in Fig. 6.

Number of paralysed rats in each of the examined groups:

Group I $\left(12^{\prime}\right)-81 \%$

Group II (14') - 90\%

Group III (3'prec $\left.+12^{\prime}\right)-27 \%$

Group IV (3'prec $\left.+14^{\prime}\right)-33 \%$

Fig. 7 shows the number of paralyzed animals.

The neurohistopathological analysis of ischemic lumbosacral segments revealed substantial differences in white and grey matter affected by ischemic preconditioning compared to "lethal" ischemia, (Plate XVIII, Fig. 2, Plate XIX, Fig. 3), i.e. without any pre-treatment. Positive findings were shown in preserving the integrity of grey and white matter almost in full extent. No signs of necrosis were seen in the investigated part of the spinal cord. The core of the dorsal horn was preserved and most of $\alpha$-motoneurons did not show any signs of damage (Plate XIX, Fig. 3, Plate XX, Figs 4, 5).

The histopathological investigation of each group of the experimental animals fully corresponded with the neurological status of rats as expressed in the index of locomotor activity.

Index of locomotor deficit

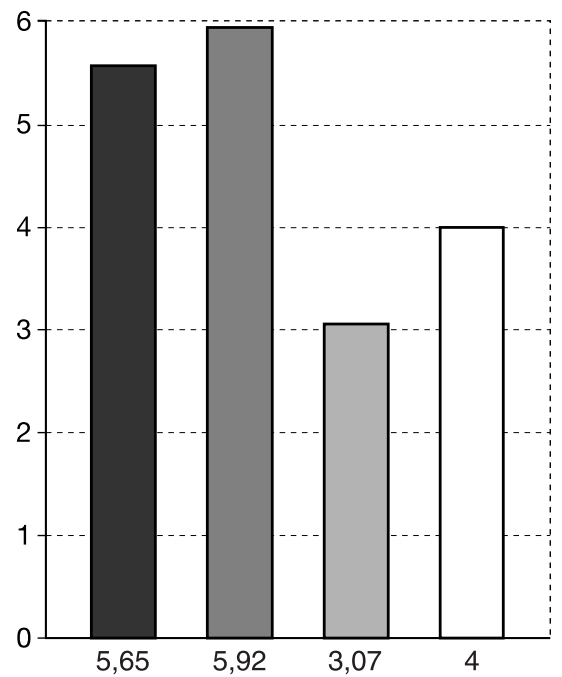

Fig. 6. Index of locomotor deficit in each experimental group of animals

\section{Discussion}

Paraplegia as a complication following the cross-clamping of the thoracic aorta was already described in 1910 by Carrel. Since that time, many methods have been developed that focus on the protection of the spinal cord affected by ischemia (Cambria et al. 1997; Cambria 1999; Nilsson et al. 2000). Even though no one of them was able to fully avoid ischemic damage of the spinal cord, each surgical intervention should involve certain techniques on a regular basis that decrease the risk of paraplegia (Pechán et al. 1996; Radoňak et al. 1997, 1999). Most investigators tend to combine more methods, whose main principles are:

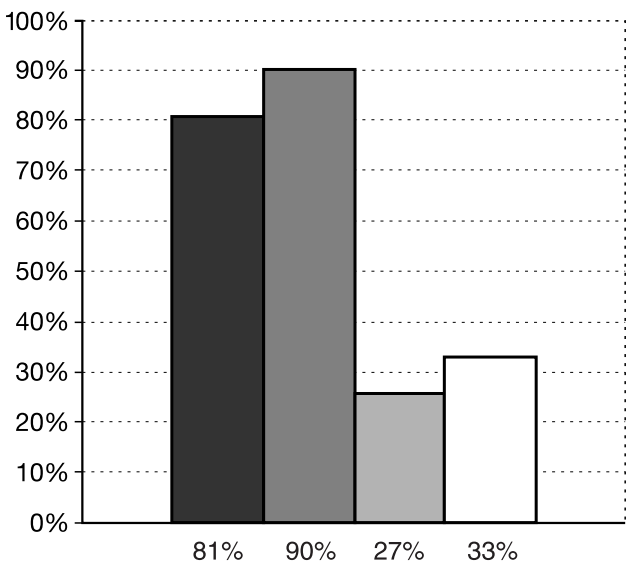

Fig. 7. Number of paralysed rats shown in percentage 
1. to establish sufficient blood pressure distal to the closed place of the aorta;

2. to maintain blood supply by using the Adamkiewicz artery.

Preventive ischemia or preconditioning was first studied by Murry et. al. in 1986. The idea of preventive ischemia was derived from the fact that the primary noxious stimulus to the organism was ischemia (Perez-Pinzon et al. 1999). It was presumed that a sublethal intervention of preconditioning could function as a way of activation of protective mechanisms in the spinal cord. Subsequently, a severe ischemic insult does not induce lethal consequences in the organism and histopathological damage is greatly reduced. Even if sublethal ischemia can develop the same qualitative changes in the nervous tissue similar to lethal ischemia, an important difference is in the extent of damage. The period of latency after this noxious stimulus is of particular importance - during this time the organism is developing protective reactions to avoid the devastating effect of ischemia during surgery. Neurohistological examination can reveal the extent of damage in the affected spinal cord.

There are two types of preconditioning: early and late. They differ in the mechanism of possible operation (Radoňak et al. 1999; Roth et al. 1998). Early preconditioning is known to involve the influence of a decreased demand of ATP, increased glycolysis, loss of ion homeostasis, etc. Late preconditioning is functioning on the base of the activation of specific genes and on the expression of stress proteins (heat shock protein) (Rahman et al. 2001; Sakurai et al. 1998).

The positive role of preconditioning is considered for the activation of adenosine A1 receptors as well. Stimulation of this receptor supports the translocation and following activation of specific isoforms of proteinkinase $\mathrm{C} 1$, and these can phosphorylate unidentified effector molecules in the cell (Šulla and Vanický 2003; Taira and Marsala 1996).

It should be noted that in experiments performed on the brain, possible mechanisms of preconditioning account for the inactivation of ion channels and for the decrease in neurotransmitter release (Nilsson et al. 2000; Perez-Pinzon et al. 1999; Radoňak et al. 1999). Consequently, the excitotoxicity decreases, and the activity of antioxidant and apoptotic enzymes increases. The nervous system has been shown to be responsive to preconditioning and the metabolism of neurons to have changed.

The experimental method of ischemic preconditioning is presented as one of the possible ways of spinal cord protection. The results of this experiment are promising: improvement of neurological incidence from $81 \%$ to $27 \%$ in the group with $12 \mathrm{~min}$ of ischemia and improvement from $90 \%$ to $33 \%$ in animals with $14 \mathrm{~min}$ of ischemia. These findings could encourage patients in the therapy of aneurysm. On the other hand, there is a reasonable consideration during the evaluation of this method, because according to previous studies there were only a few experimental results transferred with success into practice during performing clinical trials.

\section{Preconditioning ako možná ochrana ischemizovanej miechy $\mathrm{v}$ experimente}

Autori prezentujú výsledky experimentálnej štúdie skúmajúcej možnosti ochrany miechy $\mathrm{v}$ experimente. Ciel'om experimentov bolo simulovat' podmienky operácie aneuryzmy torakoabdominálnej aorty s možnost'ou následného použitia v klinike. Experimenty uskutočnili na potkanoch kmeňa Wistar albino, oboch pohlaví. Pri zasvorkovaní hrudníkovej aorty po dobu 12 minút neurologický deficit sa vyskytol u 81\% potkanov, po 14 min ischémii ochrnulo $90 \%$ potkanov. Aplikáciou ischemického preconditioningu 3 minúty s následnou recirkuláciou 30 minút a ischémiou 12 minút po 48 hodinách prežívania bolo paraplegických iba $27 \%$ potkanov, v skupine so 14 min ischémiou a preconditioningom ochrnulo $33 \%$ potkanov.

Ischemický preconditioning sa javí ako perspektívna metóda, znižujúca výskyt devastujúceho neurologického poškodenia po zasvorkovaní aorty počas operácie s možným využitím aj v klinike. 


\section{References}

Cambria RP, Davison JK, Zannetii S, L'Italien G, Atamian S 1997: Thoracoabdominal aneurysm repair perspectives over a decade with the clamp- and -sew technique. Ann Surg 226: 294-303

Cambria RP 1999: Thoracoabdominal aneurysm repair: how I do it. Cardiovasc Surg 6: 597-606

Murry CE, Jennings RB, Reimer KA 1986: Preconditioning with ischemia - a delay of lethal cell injury in ischemic myocardium. Circulation 74: 1124-1136

Nilsson B, Friman S, Gustafsson BI, Delbro DS 2000: Preconditioning protects against ischemia/reperfusion injury of the liver. J Gastrointest Surg 4: 44-49

Pecháň I, Záhorec R, Holomáň M, Plvanová A 1996: Protektívny vplyv antioxidačných vitamínov a kreatínfosfátu u pacientov pri kardiochirurgických výkonoch. (In Slovak, Protective effects of anioxidant vitamins and creatine phosphate in patiens during cardiosurgery.) Slov Lek 6: 16-19

Perez-Pinzon MA, Alonso O, Kraydieh S, Dietrich WD 1999: Induction of tolerance against traumatic brain injury by ischemic preconditioning. Neuroreport 10: 2951-2954

Radoňak J, Maršala J, Vajó J 1997: Ochrana ischemie miechy pri operáciach torakoabdominálnej aneuryzmy aorty v experimente. (In Slovak, Protection from spinal cord ischemia during surgery of experimental thoracolumbar aorta aneurysm.) Prakt flebol 6: 116-117

Radoňak J, Maršala M, Maršala J 1999: Graduovaná postischemická reoxygenácia ako ochrana ischemizovanej miechy v experimente. (In Slovak, Gradual post-ischemic re-oxygenation: protection from ischemised cord in an experiment.) Rozhl Chir 78: 105-108

Radoňak J, Maršala M, Maršala J 1999: Epidurálna regionálna hypotermia ako prevencia paraplégie pri zaklemovaní aorty v experimente. (In Slovak, Epidural regional hypothermy as a prevention of paraplegia in clamped aorta in an experiment.) Rozhl Chir 78: 109-113

Rahman A, Ustundag B, Burma O, Ozercan IH, Erol FS 2001: Neuroprotective effect of regional carnitine on spinal cord ischemia--reperfusion injury. Eur J Cardio-Thorac Surg 20: 65-70

Roth S, Li B, Rosenbaum PS, Gupta H, Goldstein IM, Maxwell KM, Gidday JM 1998: Preconditioning provides complete protection against retinal ischemic injury in rats. Invest Ophthalmol Vis Sci 39: 77-785

Sakurai M, Hayashi T, Abe K, Aoki M, Sadahiro M, Tabayashi K 1998: Enhancement of heat shock protein expression after transient ischemia in the preconditioned spinal cord of rabbits. J Vasc Surg 27: 720-725

Šulla I, Vanický I 2003: Experience with frontoparietal craniotomy in a dog - an experimental model and possible clinical implications. Folia Vet 47: 95-98

Taira Y, Marsala M 1996: Effect of proximal arterial perfusion pressure on function, spinal cord blood flow, and histopathologic changes after increasing intervals of aortic occlusion in the rat. Stroke 27: 1850-1858 
Plate XVIII

Radoňak J. et al.: Preconditioning ... pp. 307-311

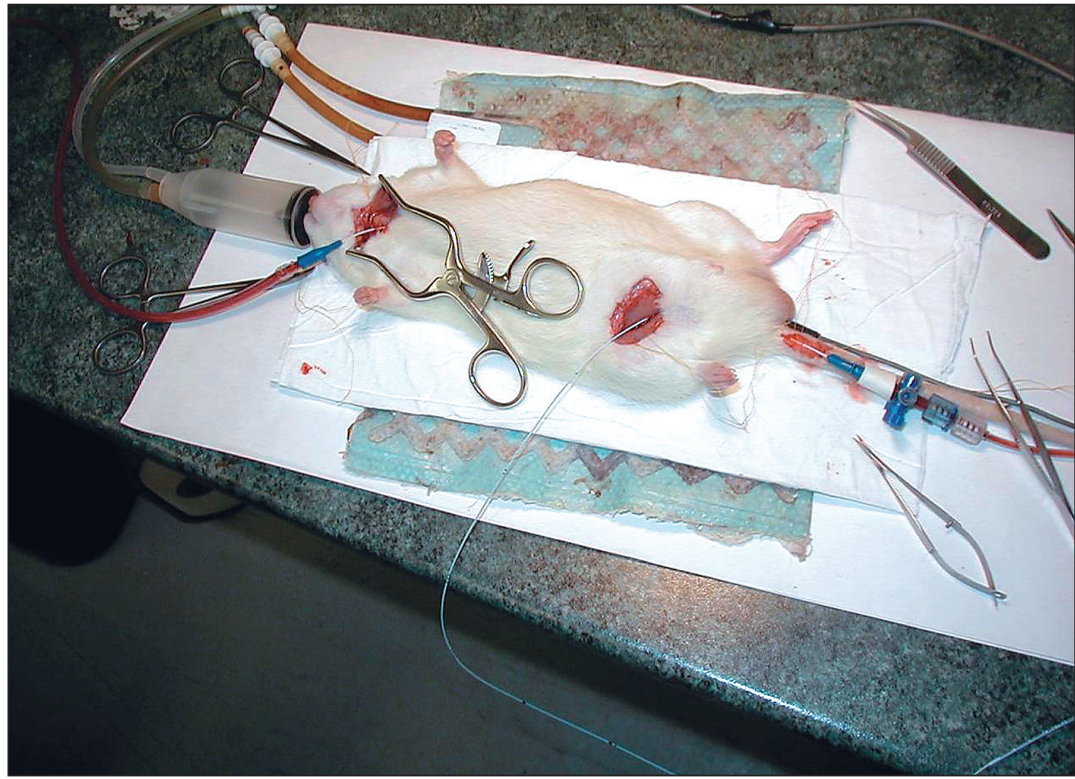

Fig. 1. View of the rat during surgery

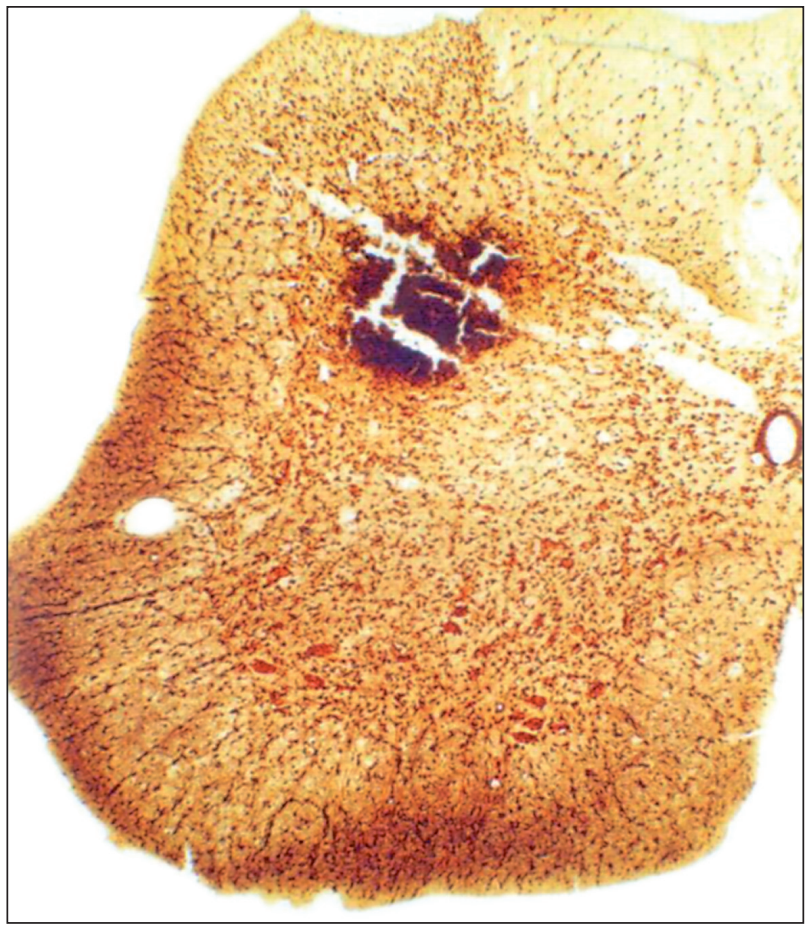

Fig. 2. Histological investigation of spinal cord section. Necrotic focus in the dorsal horn of $\mathrm{S} 1 \mathrm{segment}$ in the rat which underwent $12 \mathrm{~min}$ ischemia (impregnated according to Gallyas, magnification, $\times 72$ 
Plate XIX

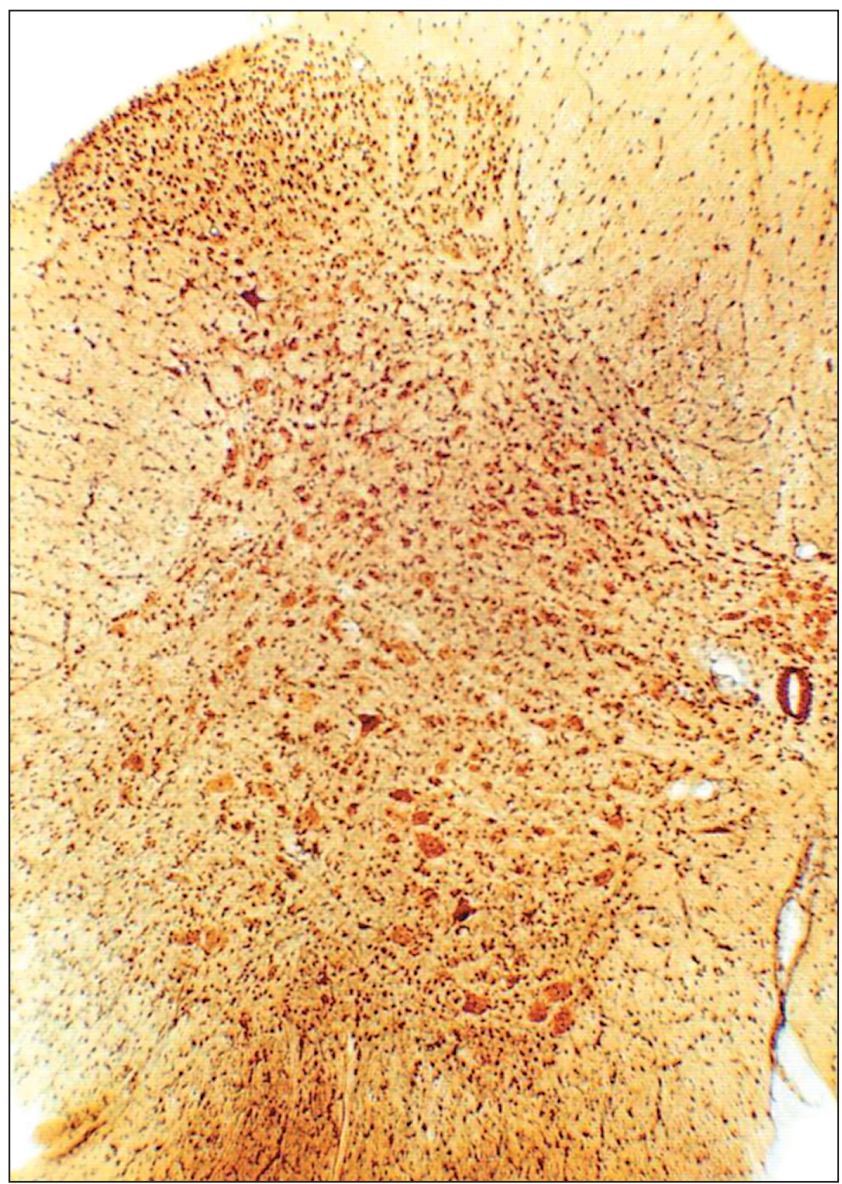

Fig 3. View of the dorsal horn - $3 \mathrm{~min}$ preconditioning and $12 \mathrm{~min}$ ischemia (impregnated according to Gallyas, magnification, $\times 85$ 


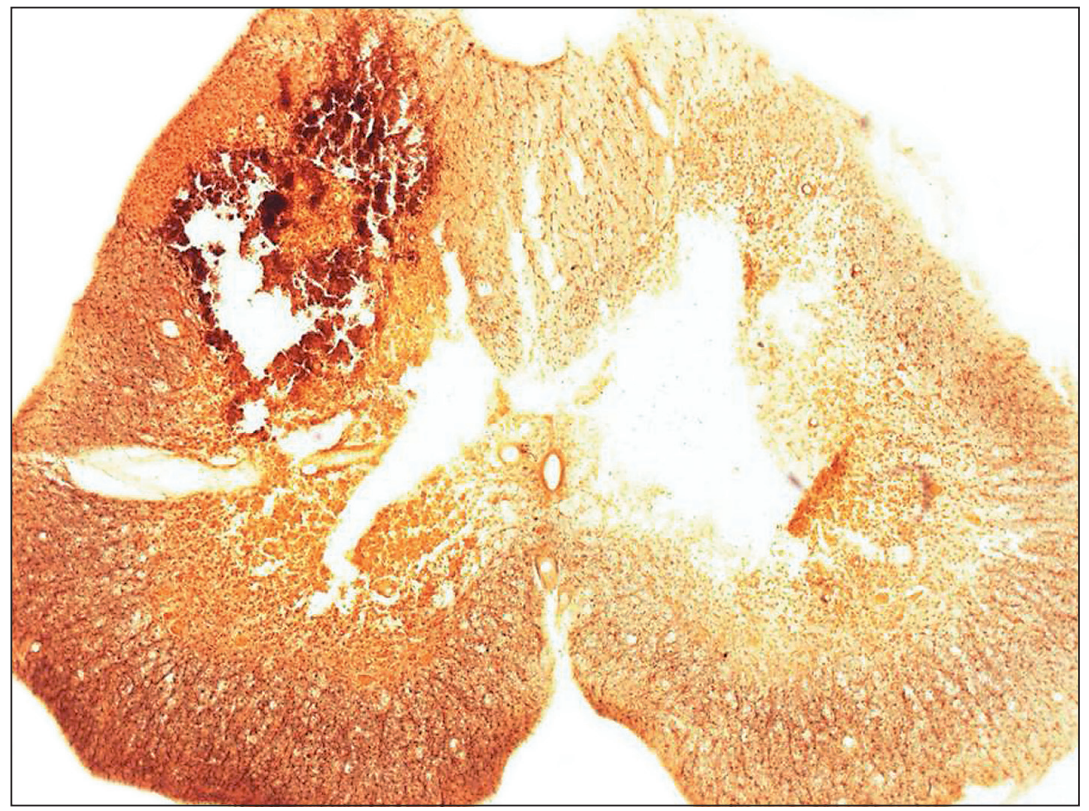

Fig 4. Extensive necrotic focus in the central part of gray and white mater of the spinal cord in a rat with 14 min ischemia (impregnated according to Gallyas, magnification, $\times 72$

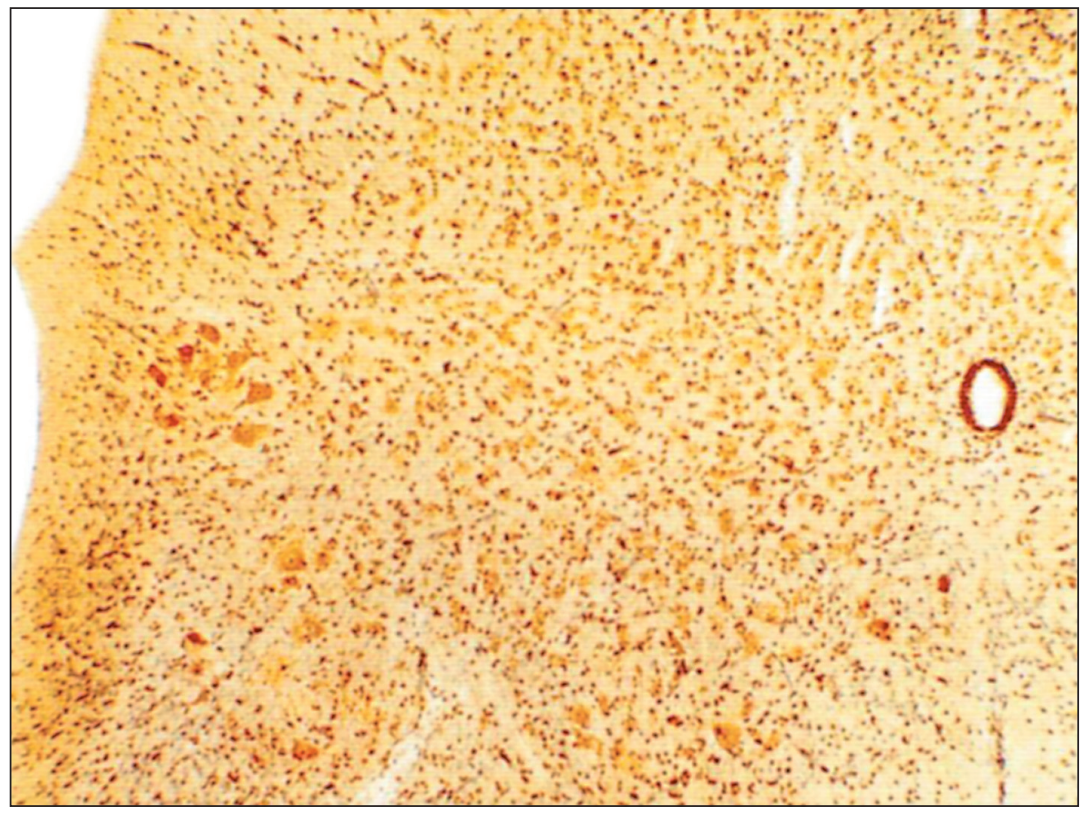

Fig 5. View of undamaged $\alpha$-motoneurons in the ventrolateral nucleus of a rat with 3 min of preconditioning and 14 min ischemia (impregnated according to Gallyas, magnification, $\times 85$ 